\title{
CD4 wt Allele
}

National Cancer Institute

\section{Source}

National Cancer Institute. CD4 wt Allele. NCI Thesaurus. Code C51128.

Human CD4 wild-type allele is located within 12pter-p12 and is approximately $31 \mathrm{~kb}$ in length. This allele, which encodes T-cell surface glycoprotein CD4, is involved in cell-cell interactions and may have a role in signal transduction. 